complete and not merely superficial was shown by the concertina-like behaviour of the tube when pulled."

\section{Summer School in Theoretical Physics and Conference on Mechanical Properties of Solids}

THE University of Bristol, in co-operation with the Institute of Physics, is arranging a Summer School in theoretical physics, with particular application to cohesive forces in metals and mechanical properties of solids, to take place during July 2-5. Lectures will be given by Prof. N. M. Mott, Dr. H. Fröhlich, and other members of the staff of the Laboratory. The course will be followed by a Conference on the Mechanical Properties of Solids (July 7-9), at which papers on the experimental and theoretical aspects of the subject will be given by research workers from Great Britain and abroad. The Summer School is intended mainly for members of staffs of Government and industrial research laboratories who wish to familiarize themselves with the theoretical aspects of subjects on which they have carried out experimental investigations. Subjects to be treated will include : cohesive forces in metals and elements of the zone theory; properties of Taylor dislocations; the Griffith crack theory; deformation of non-metals and theories of viscosity of liquids. The Conference will deal with the same subjects, and the lectures in the Summer School will be designed to provide the theoretical background for the discussions of the Conference. There will be no fee for the Conference, and it is not envisaged that everyone attending the Conference will wish to attend the Summer School. Accommodation will be reserved for a limited number at the University hall of residence, Wills Hall, Stoke Bishop, Bristol, 9. Particulars as to admission and as to the fees payable for the Summer School can be obtained either from the Secretary of the Institute of Physics, 47 Belgrave Square, London, S.W.1, or from the Director of the Department of Adult Education, University, Brist ol

\section{Symposium on Coal, Petroleum and Their Newer Derivatives}

THe Scottish Sections of the Royal Institute of Chemistry have arranged a symposium on "Coal, Petroleum and Their Newer Derivatives" to be held at St. Andrews during July 7-12. The conveners have received much help from the Principal of the University of St. Andrews, and the staff of the Department of Chemistry of the University. The symposium is designed to give industrial scientists and others a comprehensive idea of developments which have been made in recent years in heavy organic chemistry. The first part of the symposium will deal with the raw materials and their sources, the second part with chemical syntheses, and the third part with physical-chemical problems of polymerization, etc. Both academic and industrial aspects of the problem will be discussed. Each lecture will be followed by a short interval for discussion, and on the last day there will be a general discussion and the position will be reviewed. Those attending the symposium may be accommodated in the students' residences. Arrangements have been made for accommodation from arrival on the evening of July 5 , until the morning of July 12. Bookings will commence on March 1, and applications should be forwarded to the Secretary, Royal Institute of Chemistry, 30 Russell Square, London, W.C.1.

\section{Royal Microscopical Society: Officers}

THE following have been elected officers of the Royal Microscopical Society: President: Dr. J. R. Ludford; Vice-Presidents : Dr. G. M. Findlay, Mr. C. F. Hill, Dr. James A. Murray, Dr. T. E. Wallis ; Hon. Treasurer: Mr. S. R. Wycherley; Hon. Secretaries : Mr. F. C. Grigg, Dr. H. Moore; Ordinary Members of Council: Mr. F. D. Armitage, Dr. L. P. Clarke, Dr. F. Greenshields, Major Maxwell Knight, Mr. Chetwynd Palmer, Mr. R. Ross, Mr. D. J. Scourfield, Mr. J. Smiles, Mr. H. Gilbertson Smith, Mr. E. Wilfred Taylor, Dr. C. Tierney, Mr. J. M. Watson; Hon. Editor : Dr. G. M. Findlay; Hon. Curator of Instruments : Dr. C. Tierney; Hon. Curator of Slides : Mr. N. Ingram Hendey; Hon. Librarian : Mr. R. Ross.

\section{Royal Meteorological Society: Officers}

THE following have been elected officers of the Royal Meteorological Society : President, Dr. G.M. B. Dobson ; Vice-Presidents, W. Dunbar, G. Manley, Sir Charles Normand, J. F. Shipley ; Treasurer, W.M. Witchell ; Secretaries, E. L. Hawke, Wing-Comdr. R. M. Poulter ; Scottish Secretary, A. J. Drummond; Foreign Secretary, L. C. W. Bonacina ; Editor, Dr. R. C. Sutcliffe; Council, A. C. Best, G. S. Callendar, J. S. Forrest, Capt. L. G. Garbett, Major H. C. Gunton, W. G. Kendrew, I. T. D. Kirkpatrick, Dr. A. R. Meetham, Dr. F. J. Scrase, P. A. Sheppard, A. E. Slater, Dr. T. W. Wormell.

\section{Announcements}

Princess Elizabeth has been elected a Royal Fellow of the Royal Society.

ProF. A. A. HaLL, Zaharoff professor of aviation and head of the Department of Aeronautics, Imperial College of Science and Technology, has been appointed a member of the Air Safety Board.

Dr. Franz Weidenreich, of the American Museum of Natural History, is the first recipient of the newly created Viking Fund Medal and Prize in Physical Anthropology, for his many contributions to palæo. anthropology, and especially for his very important recent studies on fossil man in China and Java. Dr. Weidenreich was presented with the Viking Fund Prize of 1,000 dollars at the annual meeting of the American Association of Physical Anthropologists on December 28.

Mr. C. L. BIRD, lecturer in dyeing in the University of Leeds, has been appointed editor of the Journal of the Society of Dyers and Colourists in succession to the late Prof. F. M. Rowe.

To commemorate the centenary of the Chemical Society, which was founded at a meeting on February 23,1841 , in the rooms of the Society of Arts, a special joint meeting of the two Societies will be held at the Royal Society of Arts, John Adam Street, Adelphi, W.C.2, on February 19 at 5 p.m. Viscount Bennett, president of the Royal Society of Arts, will preside, and Sir Harold Hartley will speak on "A Century of Chemistry". Tickets of admission will be available on request to the Secretary, Royal Society of Arts.

OwING to continued public interest, the "March of Time" film entitled "Atomic Power" will continue to be shown at the Science Museum until February 23, by courtesy of Messrs. 20th Century Fox Film Co., Ltd. It is being shown on weekdays at 2.30 p.m., and on Sundays at 3.15 and 4.15 p.m. Admission is free. 